\title{
A Study on Dominant Education Philosophy in Classrooms: The Case of Colleges of Technology (CoT) in the Sultanate of Oman
}

\author{
Siraj Kariyilaparambu Kunjumuhammed ${ }^{*}$, Bassam Khalil Hamdan, Vaidehi Pandurengan, \\ Sheikha Al Subhi
}

Department of Business Studies, Higher College of Technology, University of Technology and Applied Science, Sultanate of Oman

Received September 11, 2020; Revised November 10, 2020; Accepted November 19, 2020

\section{Cite This Paper in the following Citation Styles}

(a): [1] Siraj Kariyilaparambu Kunjumuhammed, Bassam Khalil Hamdan, Vaidehi Pandurengan, Sheikha Al Subhi, "A Study on Dominant Education Philosophy in Classrooms: The Case of Colleges of Technology (CoT) in the Sultanate of Oman," Universal Journal of Educational Research, Vol. 8, No. 12A, pp. 7881-7893, 2020. DOI: 10.13189/ujer.2020.082577.

(b): Siraj Kariyilaparambu Kunjumuhammed, Bassam Khalil Hamdan, Vaidehi Pandurengan, Sheikha Al Subhi (2020). A Study on Dominant Education Philosophy in Classrooms: The Case of Colleges of Technology (CoT) in the Sultanate of Oman. Universal Journal of Educational Research, 8(12A), 7881-7893. DOI: 10.13189/ujer.2020.082577.

Copyright $\mathrm{C} 2020$ by authors, all rights reserved. Authors agree that this article remains permanently open access under the terms of the Creative Commons Attribution License 4.0 International License

\begin{abstract}
Educational philosophies guide decisions on curriculum, teaching and learning pedagogies and assessment. In other words, students' learning experience in a higher education institution (HEI) is deeply influenced by the underlying educational philosophy of the HEI and the academic staff. This research examines the dominant educational philosophies of academic staff in the Colleges of Technology (CoT) in the Sultanate of Oman. A questionnaire that focuses on essential features of various student-centered and teacher-centered educational philosophies is distributed online. The statements used in the questionnaire start with, "I allow my students" or "I focus on" to reflect the current teaching practices. Two hundred academic staff from the department of business studies of seven CoTs participated in the study. Two significant inferences were drawn based on the analysis. Firstly, the educational philosophy of staff is influenced by the HEI's preferred educational philosophy articulated in their vision and mission statements and not by their gender, nationality and years of experience. The second and foremost inference is the staff's preference to use the positive sides of both student-centered and teacher-centered educational philosophies in classrooms. This refutes the observation of superiority or usefulness of a single educational philosophy in enhancing student learning experience and attainment of graduate attributes
\end{abstract}

Keywords Educational Philosophy, Higher Education
Institutions, College of Technology, Academic Staff

\section{Introduction}

It is well-conceived that educational philosophies are the guiding principles of pedagogically meaningful teaching and learning practices from a holistic perspective. Educational philosophies are deeply embedded ontological assumptions that reflect educators' views on curriculum and pedagogies [46]. With a holistic perspective, education philosophy influences the educational beliefs of teachers [20] [11] [22] [15], their underlying belief about teaching and learning [45] [5], their attitudes, values, and decisions [15] and a significant determinant in organizing the classroom environment. An educational philosophy provides a foundation for understanding and for guiding decisions about curriculum, teacher-learner relationships, and professional practice. However, aligning one's education philosophy with that of the higher education institution (HEI) where he/she works is imperative for achieving excellence in education. Two significant issues require consideration in this context. First, although the teacher's educational philosophy emanates from personal values, beliefs, and experiences, the alignment with the HEI educational philosophy at times differs. A teaching philosophy is a 
powerful framework for exploring one's beliefs about student learning, classroom leadership, assessment, teaching and learning styles, and programmatic development [48].Second, empirical studies observed that teachers often recognize a disparity in what they believe and what they do in practice [36] [15]. The difference may occur; either teachers reject HEIs underlying educational philosophy, or they follow the educational philosophy of HEI due to political, social, and economic constraints. In both of these situations, a compromise result, which impacts the quality of teaching and learning practices.

Indeed, the idea that educational philosophy governs the teacher's behavior in the classroom doesn't necessarily mean that a specific educational philosophy guides the actions that the teacher believes. Often, the best approach is one that is labeled as being inclusive of the positive sides of a wide range of different philosophies. A clear educational philosophy seeks to identify and elucidate a broader, often implicit, principles and themes that are not necessarily exemplified in the HEI's strategic preferences but are consistent with the beliefs and values that define and focus the vision and mission [24]. We defer the argument that there is no one-best philosophy the adherence to which will qualify a 'best teacher' instead, it is the blend of different approaches that define a good teacher. We believe that 'excellence' results when the education philosophy of teachers is compatible with HEIs underlying expectations from the teachers. It is because we often define excellence against a set of values, beliefs, and outcomes that HEI strives to achieve. Besides, the factors that influence educational philosophy include the policies and standard operating procedures, and the facilities available for teaching and learning. Together, it contributes to either a student-centered or teacher-centered teaching and learning pedagogy or a combination of both. Understanding the philosophies of education, in a way, is helpful for different stakeholders to examine whether HEI's teaching and learning are in alignment with the vision and mission and expected graduate attributes.

The primary role of a clearly defined educational philosophy is to contribute towards the evolving of policies and plans of a system of education that permits the moral, mental and physical development of the community and engenders spiritual and human values [41]. However, the influence of education philosophy is not only limited to teaching and learning but also in other roles such as advising, counseling, research, and consulting profiles of teachers. Conflict may also arise when educators with different educational philosophies are involved in the setting up of curriculum and instructional designs [31]. Hence, it is highly relevant that HEIs should evaluate the dominant education philosophy of teachers and align their philosophy to the broad educational philosophy outlined by the HEI in its vision, mission, and value statements.

Three critical trends underline the contemporary curriculum policy; (1) the introduction and growing importance of national qualifications frameworks, (2) the emphasis on learning outcomes, and (3) the move from the disciplinary subject-based approach to a more generic curriculum [34]. Though the outcome-based curriculum requires student-centered teaching, it doesn't prevail in all HEIs. This is often due to increased pressures placed on teachers within these establishments, and therefore less time is devoted to creating innovative teaching methods. The field of education is confronted with incessant challenges on account of changes in the dynamics of teaching and learning, the expectations from stakeholders and the quality accreditation requirements. The best way to adapt to the requirements is though aligning its teaching and learning philosophy to the strategic priorities of the HEI. Such integration requires HEIs to recruit, reward, and retain academic staff who are a strategic fit to the HEIs educational philosophy.

While explaining the educational philosophy, we are not restricting its scope to what a teacher does in the classroom; instead, we address the question "Why teachers behave in a particular manner inside the classrooms?." For instance, a teacher focusing on 'rewards and punishments are necessary for classrooms' often believes in the intrinsic nature of humans to react to internal or external stimuli. The underlying educational philosophy or the guiding principle of behavior relevant here is behaviorism.

Against this backdrop, we developed a scale to measure the dominant education philosophy of current and prospective academic staff in HEIs. We used the research instrument to evaluate the education philosophy of business studies teaching staff in the Colleges of Technology (CoT) in the Sultanate of Oman. This research offers two significant contributions. First and foremost, this research developed a valid and reliable scale to measure the dominant educational philosophies in any HEI. The second significant contribution is the critical review of the empirical literature review on the subject.

\section{Educational Philosophy - Different Perspectives}

In empirical research, the idea that educational philosophy sets the broad guidelines that orient education for a purpose has evolved ever since the concept of reasoned inquiry was championed by Socrates and his descendants. The early philosophers on education viewed that education should be offered to all and should foster reason or rationality. Since then, different educational philosophies have emerged, viewing education from different perspectives. Also, there were attempts to develop a scale to measure the educational philosophies, as a subtle movement in the initial phase. The education philosophies provided a broad outlook on what education 
should achieve and are often influenced by the political, social, and economic environment in which these philosophies were propagated. Some of the philosophers focused on abstract philosophical issues while others concentrated on a holistic view about education and its purpose. The argument supporting and criticizing these philosophies was rooted deeply in its ambiguity and explained the underlying differences in perception of what education ought to be, irrespective of the environment in which the beliefs emerged.

We emphasize two significant perspectives in this section. At first, a detailed outlook on the different educational philosophies that have evolved is discussed, and then, on the need to revise the scale which is available to measure the educational philosophies. An empirical research investigated education practices using the Principles of Adult Learning Scale (PALS) and concluded that instructors have a strong preference for a teacher centered style of teaching and a disconnection between what instructors do in the classroom and what they feel is effective instruction [29]. Two critical issues are relevant in this review. As indicated, the educational philosophy of teachers differs between a teacher-centered instructional philosophy and a student-centered active learning philosophy. The second important issue is the mismatch between instructors' philosophy and what they practice in classrooms. This mismatch is not well drawn in empirical research.

There is an implicit assumption that different education philosophies don't contradict each other entirely but are built upon an earlier philosophy to address the changes in the broad political, social, cultural, and economic environment. For instance, while comparing a constructionist and constructivist education philosophy, it is argued that while the constructivist teacher sets up the learning environment for students that fosters individual learning and presents a problem to be solved, the constructionist teacher sets up the environment for collaborative learning for the students [35]. However, to provide effective education, it is required that the needs of teachers, students, and institutions intersect during pedagogical innovations and should be interceded with each other [33].

The education system has moved from a push-based or producer-centric system to a pull-based or customer-centric system [4]. Different educational philosophies exist. Educational theories can also be classified as behaviorism, cognitivism, and constructivism [45]. The most important educational philosophies that this research focuses upon are constructivism, reconstructionism, progressivism, humanism, perennialism, positivism, behaviorism, and essentialism. Broadly, we can classify these philosophies into student-centered and teacher-centered teaching and learning philosophies. It is labeled as instructivist-based practices, focusing on didactic lectures, rote memorization, and high-stake exams [33]. Among the various education philosophies listed, perennialism, behaviorism, and essentialism are considered as teacher-centered, while progressivism, humanism, reconstructionism, and constructivism are student-centered teaching and learning philosophies.

\subsection{Student-Centered Teaching Philosophies}

Given its positive impact, many experts in education have advocated constructivist education pedagogy to develop skills needed in the knowledge societies [19] [33]. They explained that the teachers should use a constructionist approach to set up their classroom and guide their students throughout the course time, so that students can work collaboratively on a project to learn the critical concepts to be developed [35]. The main idea behind constructivism is the recognition of sensation and cognition of the experiences to actively 'build' learners' understanding and knowledge [43]. It is a student-centered teaching and learning philosophy where the role of the teacher is to facilitate a conducive environment for learning. Many theorists and scholars have categorized constructivism into three forms; sociological, psychological, and radical constructivism [44]. A constructivist philosophy puts forward the fundamental role of education in the development of an individual, his knowledge and skills, survival, and adaptation. Although constructivism as an education philosophy contrasts with objectivist epistemology and positivism, it postulates that knowledge cannot exist outside our minds and should be constructed based on the experiences [17]. Cognitive design, according to the constructivist philosophy, provides adaptation and an organism's survival and also life experiences with which the learner can gain a stable picture of the world [8]. The key attributes of educators focusing constructivism include; focus on developing own understanding [2], focus on recollecting and relating knowledge, focus on experiential learning [13], focus on the application based learning [37], focus on freedom in learning, focus on the interactive learning, and focus on relating learning to real life [10].

The primary focus of reconstructionism/Critical theory is the relevance of education to create a better society. Curriculum focus on social reforms and pedagogies is designed to prepare learners to develop a new social order. It is a radical philosophy of education [9] [38]. This philosophy is an extension of progressivism and is based on pragmatism [45]. The proponents of critical theory consider that education should result in a society that is rearranged and reformed. The critical attributes of educators who propose reconstructivism/critical theory focus on creating responsible citizens, focus on realism (addressing the real problems in the society), emphasize on futuristic learning, focus on free expressions, focus on liberalism in the discussion, and focus on creating 
constructive reforms.

Progressivism, as student-centered teaching pedagogy, asserts that learning should facilitate and nurture student's development. This philosophy considers education as life, believes in the change and rejects all kinds of stability and absolute facts [23]. Educators proposing progressivism consider it as a state of 'learnification' with a loose connection to theories, but a more visible link to the practices and policies of education [6]. Educational progressivism has become metaphorically cordoned off from the wider world of social and political struggle [30]. However, emphasizing a critical curriculum approach may neglect the importance of curriculum during pressure to renew the curriculum in higher education [26]. Educators who stress on progressivism focus on interaction and participation, customizing training, focus on the needs of the dynamic environment, learning by pursuing their interest, and focus on practical and problem-solving.

Humanism, a student-centered teaching philosophy, emphasis that learners should be in control of his/her destiny; hence learning happens when a learner is self-motivated and takes control of his learning behavior. Humanizing humans, is to achieve self-actualization, self-understanding, and self-realization people to learn optimally [14]. The central and dominant ideology in humanism is on the learner, interest, and development [14], the inner world of the learner, thoughts, emotions, and feelings [25] [21], autonomy and dignity of human beings [7]. In this perspective, humanism becomes a thoroughly contested term and widely denounced from a range of intellectual positions from behaviorism to post-modernism [32]. Hence the educators who emphasize humanism as their key philosophies focus on their teaching and learning; accountability in learning, creative thinking, enhance curiosity to learn, learn without stress, compassionate learning, self-evaluation and consent benchmarking, motivation to learn and maintain human dignity.

\subsection{Teacher-Centered Teaching Philosophies}

Educators following perennial philosophy focus on a well-disciplined and carefully organized classroom and provide importance to mastery of the content and development of reasoning skills. In other words, perennialism focuses on classical idealism and realism [23]. Both perennialism and essentialism are based on philosophies of idealism and realism [39]. From an idealist point of view, a perennialist view that truth is universal and unchanging. It is also independent of time, place, and the immediate reality that surrounds us.

Similarly, the realistic view emphasizes rationality and the relevance of education in training our intellect in search of truth [3]. Thus, the advocates of perennialism consider a universe with its spiritual sides; they consider the position of the human in the universe metaphysical
[47]. Educators who emphasize perennialist education philosophy in their teaching and learning will focus on; understanding concepts in totality, fundamentals in learning, the capability to learn, exploring and self-discovery, and consider that knowledge is unquestionable.

Basically, the positivist philosophy postulates that reality is to be discovered, which is objective, rational, and independent of the observer. Thus, it assumes the existence of a world beyond our ideas [27]. Based on a study to examine the pitfalls in the varied and contradictory ways in which positivism is explained, it is concluded that positivism is of high value, the educators facing a worldwide drift from natural sciences and an increasingly strident anti-science lobby in higher education institutions [28]. Unlike the perennialist view, positivism compares an ideal model in theory with reality. The educators who emphasize on positivism attributes focus on the multicultural background of leaners and experiments, exploring truths, and statistics on learning.

Behaviorism, as a teacher-centered teaching philosophy, is rooted in psychology and focuses on conditioning student in a classroom setting. According to this philosophy, student behavior needs to be shaped deliberately, and includes methodological behaviorism, psychological behaviorism, and analytical or logical behaviorism [16]. The basic notion of behaviorism is the setting up of the environment by the teacher, who plays a central role in the operant conditioning of the students, using rewards and punishments. The teacher is considered as the role model. Educators who emphasize behaviorism in teaching and learning focus on maintaining discipline and order in classrooms, focus on time management, monitor students in and outside the class, emphasize on authoritative knowledge and focus on feedback in learning.

Essentialism is an educational philosophy that focuses on embedding common core knowledge [1] [18] to the learners in a systematic and disciplined manner, thoroughly and rigorously. The term essentials denote the core knowledge or main things in academic knowledge. Essentialism is based on realism and idealism [23]. The essentials in any subject are emphasized in the curriculum, teaching pedagogies. Thus, we can view essentialism as a very conservative educational philosophy. Educators who emphasize essentialism as core educational philosophy often focus on intellectual disciple in the classrooms, interpreting essentials of the subject, memorization and learning core subjects.

A scale is developed to measure educational beliefs of teacher and prospective teachers, which consisted of five factors; perennialism, essentialism, progressivism, reconstructivism, and existentialism [45]. The scale consisted of 40 Likert Scale items. A similar scale is developed to measure the dominant education philosophy among faculty members in Yuzuncu Yil University [47]. 
The primary focus of the instrument was to measure four major educational philosophies and included perennialism, essentialism, progressivism and reconstructionism. A philosophy preference assessment scale is also available with 39 items to measure the educational philosophy [15].

\section{The Context}

Colleges of Technology (CoT) is the second-largest higher education institution in the Sultanate of Oman. There are seven CoTs in the country offering undergraduate programs in business studies, information technology, applied science, engineering, fashion design, photography, and pharmacy subjects. CoTs function under direct supervision from the Ministry of Manpower. The idea behind the formation of CoTs was to address the skill shortage gap in the country. The undergraduate programs are four-year programs, classified into foundation and post-foundation department. Students who enter CoTs must undergo a foundation program in the English Language Center. The admission to the post-foundation department is given only after the successful completion of the foundation program. In the post-foundation departments, there are three levels of study; diploma, advanced diploma, and bachelor. Student progression to the advanced diploma and bachelor depends on their cumulative grade point average (CGPA) and the IELTS/TOEFL or foundation level exit score. Students who don't meet the guidelines are graduated at diploma or advance diploma level provided that they have successfully completed all the courses and secured the minimum CGPA for certification and completed their On the Job Training (OJT). OJT is an 8-week program wherein students have to work in an organization, public or private, in their area of specialization.

All the academic and non-academic activities of the CoT are governed by its vision and mission statements. The strategic plans set the strategies, sub-strategies, goals, and measures, and key performance indicators. Strategic plans usually are five-year plans and are divided into a set of operational plans, which is a short-term plan spanning one year. A strategic plan achievement report (SPAR) is prepared at the end of every year to measure achievement and progress. Operational plans are revised based on the SPAR to ensure that the HEI achieves its SP at the end of 5 years.

A reason why CoTs are selected for this study is the emphasis it had given for educational philosophy explicitly in its vision and mission statements. The $4^{\text {th }}$ strategic plan for 2013-2018 (and was extended until December 2019) highlights the vision and mission as follows;

Vision statement: "We will be a leading technological institution, providing high-quality teaching and learning to prepare and empower the
Omani professionals of the future so that they can contribute to national socio-economic development."

Mission statement: "To deliver high-quality student-centered education that produces competitive graduates who enter the labor market with confidence, strong technological and personal skills, and are prepared for a life of contribution and success."

As may be observed, student-centered education is given strategic priority to produce competitive graduates. In the graduate attribute statement, the ten major attributes of competitive graduates are explained and include; (1) Well-disciplined and committed to hard work and a high standard of productivity, (2) Ability to apply the knowledge and skills to a diverse and competitive work environment, (3) Ability to think critically, analyze and solve problems, (4) Possess high degree of competence in using information and communication technology, (5) Professionally competent and up-to-date in their field of specialization in a changing global environment, (6) Ability to gather and process knowledge from a variety of sources, and communicate effectively in written and spoken English, (7) Ability to effectively demonstrate and apply good interpersonal skills in teamwork and leadership roles, (8) Committed to self-development through lifelong learning, (9) Socially responsible citizens aware of contemporary issues in contributing to national development, and (10) Ability to demonstrate and apply their entrepreneurial skills.

The elements of various student-centered philosophies are visible in the vision and mission statements and graduate attributes. HEI is also committed to the stakeholders by proclaiming its purpose to offer a student-centered teaching and learning environment on the campus. This statement of purpose is further deliberated and verified, taking feedback from the staff. We examine whether there is a match between the HEIs educational philosophy and the academic staff's educational philosophy. As highlighted earlier, the study is focused on one department, i.e., business studies, which may be extended into other departments in the future.

\section{Research Methodology}

\subsection{Questionnaire Design}

The scale used in this research is developed based on the literature review and expert feedback. A customized scale to measure the dominant educational philosophy is not available; however, there is an individual scale available to measure the various educational philosophies among academicians. A structured questionnaire is used to collect feedback from academic staff in business studies in the Colleges of Technology. The initial survey instrument 
is designed based on diverse and seemingly focused research on various educational philosophies. We have incorporated expert feedback on survey questions and the measurement scale before deploying a pilot study. Developing a scale and measuring their reliability is difficult for an attitude scale because human beings are constantly changing due to experiences. Based on the pilot study among 20 academic staff selected randomly, we have incorporated a few changes and finalized the survey instrument. The changes were primarily on statements used to measure the dominant philosophy. Besides the demographic profile, the questionnaire included forty-six statements in a five-point Likert Scale. The scale included; "Strongly Agree=5", "Agree=4", "neutral=3", "Disagree $=2$ ", and "Strongly Disagree $=1$ ". The statements often began with phrases such as "I allow my students", or "My students are", or "I involve". In this way, it is possible to explain an educational philosophy and gain insight into the way academic staff perceive their teaching and learning experiences. The education philosophy includes both student-centered and teacher-centered philosophies. In this research, we examined the relevance of eight major education philosophies; behaviorism, constructivism, essentialism, humanism, perennialism, positivism, progressivism and reconstructivism.

The internal consistencies of the scale were measured through computing Cronbach alpha $(\alpha)$. The scale includes five items for progressivism $(\alpha=0.847)$, six items for reconstructionism $(\alpha=0.852)$, seven items for constructivism $(\alpha=0.895)$, eight items for humanism $(\alpha=$ $0.914)$, three items for positivism $(\alpha=0.784)$, six items for behaviorism ( $\alpha=0.801)$, four items for essentialism ( $\alpha$ $=0.704)$, and seven items for perennialism $(\alpha=0.808)$. As observed, all the items of the scale reported a Cronbach alpha $(\alpha)$ above 0.70 [41] [42], which is the acceptable Cronbach alpha score $(\alpha)$. The items and the scale were developed after rigorous literature review, expert feedback, and the comments received were based on the pilot study. Hence the scale is used, and data are obtained from the staff. Although it is generally agreed that the general threshold of Cronbach's alpha is 0.70 , the decisions on the survey instrument were taken considering the underlying educational philosophy, scale, number of items number of dimensions to be investigated. The inter-item correlation was also computed to determine the relevance of statements [12].

We have utilized google forms to conduct a survey online. The study objectives, information related to the researchers and their affiliation are included in the introductory paragraph of the survey form. In addition, we have emailed a formal letter to the head of academic departments (HoDs) in each of the CoT requesting their participation in filling the survey form. The data's ethical considerations and confidentiality clause were explicitly highlighted in both the official letter to HoDS and the online questionnaire. Staff consent is requested in the beginning of the survey, and they were given the right to withdraw from filling the survey at any point of time. The confidentiality clause mentioned that the data would be used only for the purpose specified and in a summative format.

\subsection{Data Collection and Descriptive Statistics}

The population consisted of academic/teaching staff working in the seven Colleges of Technology (CoT), the second largest HEI in the Sultanate of Oman. 200 academic staff from the seven CoTs participated in the survey. The data collected were tabulated, coded, and analyzed using the Statistical Package for Social Sciences (SPSS). $63 \%$ of the participants were male, and $90 \%$ of the staff were Non-Omanis, who were primarily from India, Philippines, Pakistan, Egypt, Tunisia, Malaysia, and Sudan. $87.4 \%$ of Non-Omanis belonged to India.

Table 1 shows the age, qualification, and nationality of participants. The analysis shows that participants are fairly distributed to different age groups, with the highest number of participants $(35.00 \%)$ in the age group between 40 years and 45 years. $49 \%$ of the participants hold a Ph.D. in their specialization, while $51 \%$ hold a Master degree.

Table 1. Age, Qualification, and Nationality

\begin{tabular}{|c|c|c|c|c|c|}
\hline Age & $\%$ & Qualification & $\%$ & Nationality & $\%$ \\
\hline Less than 30 Years & 0.50 & Master & 51.00 & Omani & 10.00 \\
\hline 30 Years -35 Years & 12.00 & $P h D$ & 49.00 & Non-Omani & 90.0 \\
\hline 35 Years - 40 Years & 25.00 & & & & \\
\hline 40 Years -45 Years & 35.00 & & & & \\
\hline 45 Years - 50 Years & 16.50 & & & & \\
\hline Above 50 Years & 11.00 & & & & \\
\hline
\end{tabular}


Table 2 shows participants specialization and professional experience. $47 \%$ of them are specialized in accounting and finance, while human resource management (HRM) and marketing specialization are $24 \%$ and $19 \%$, respectively. $54 \%$ of participants have a minimum of 15 years professional experience, while $30.5 \%$ of the participants have professional experience between 10 years to 15 years. Participants also belong to general management (7.5\%), Management Information Systems (2.0\%) and Economics (0.5\%).

Table 2. Specialization and Experience

\begin{tabular}{|c|c|c|c|}
\hline Specialization & $\%$ & Experience & $\%$ \\
\hline $\begin{array}{c}\text { Accounting and } \\
\text { Finance }\end{array}$ & 47.0 & Less than 5 years & 3.5 \\
\hline HRM & 24.0 & $5-10$ years & 11.0 \\
\hline Marketing & 19.0 & $10-15$ years & 30.5 \\
\hline $\begin{array}{c}\text { General } \\
\text { Management }\end{array}$ & 7.5 & Above 15 years & 54.0 \\
\hline MIS & 2.0 & & \\
\hline Economics & 0.5 & & \\
\hline
\end{tabular}

Table 3 shows the number of participants from each CoT. $33.7 \%$ of the participants belong to Higher College of Technology. $16.1 \%$ of participants are from Shinas College of Technology, while $13.6 \%$ are employed in Ibra College of Technology. Each college operates in a different environment although the overall supervision vests with the Ministry of Manpower.

Table 3. Number of Staff Participated from CoT

\begin{tabular}{|c|c|c|}
\hline College & $\begin{array}{c}\text { No. of staff participated } \\
\text { in the survey }\end{array}$ & $\%$ \\
\hline $\begin{array}{c}\text { Al Musanna College of } \\
\text { Technology }\end{array}$ & 19 & 9.5 \\
\hline Ibra College of Technology & 27 & 13.6 \\
\hline Ibri College of Technology & 15 & 7.5 \\
\hline Shinas College of Technology & 32 & 16.1 \\
\hline Nizwa College of Technology & 20 & 10.1 \\
\hline HCT College of Technology & 68 & 33.7 \\
\hline Salalah College of Technology & 19 & 9.5 \\
\hline
\end{tabular}

\section{Dominant Educational Philosophy}

In this section, the analysis focuses on two major aspects. Initially, we analyze the analysis of the dominant philosophy using mean and standard deviation $(\overline{\mathrm{x}}$ and $\sigma)$. One-way ANOVA is used to verify whether any significant difference exists in the perception of faculty members when classified based on their gender, specialization, institution, nationality, and years of experience. In the second section, the various elements in each educational philosophy are explained based on the preference, calculated using mean and standard deviation $(\overline{\mathrm{x}}$ and $\sigma)$.

Table 4 summarized the perception of faculty on various educational philosophies. It is obvious from the analysis that progressivism is the dominant educational philosophy in the department of business studies $(\bar{x}=4.40$, and $\sigma=0.638)$, followed by reconstructionism $(\overline{\mathrm{x}}=4.34$, and $\sigma=0.62)$, constructivism $(\overline{\mathrm{x}}=4.29$, and $\sigma=0.629)$ and humanism $(\overline{\mathrm{x}}=4.25$, and $\sigma=0.658)$. The results confirm the predominance of student-centered teaching and learning practices in HEIs. This is in alignment with the HEI vision and mission statements. Progressivism focuses mainly on promoting learning to pursue students' interests, focus on interaction and participation, customizing the learning to the learner's requirements, focus on practical and problem-solving skills, and finally, the thrust on the needs of the dynamic environment. A curriculum built on the needs of stakeholders and delivered using a pedagogy that focuses on critical thinking, real-life learning, and problem-solving skills is the essential to pursue a progressive education philosophy. On the other hand, among the teacher-centered teaching and learning practices, behaviorism reported the highest mean and standard deviation $(\overline{\mathrm{x}}=4.11$, and $\sigma=0.620)$ followed by essentialism $(\overline{\mathrm{x}}=3.96$, and $\sigma=0.708)$, and perennialism $(\overline{\mathrm{x}}=3.88$, and $\sigma=0.736)$. The analysis seems to support the claim that though student-centered teaching and learning practices are dominant in HEI, the academic staff also focus on certain elements of teacher-centered practices (such as a focus on attendance, class discipline, etc.,) which are evident from the scores of teacher-centered teaching and learning philosophies.

The above analysis proclaims a broad view of the alignment between the teacher's education philosophy and the institution's educational philosophy. However, the alignment is not a guarantee of the practices followed in the classrooms. It can be explained by examining the key aspects of each philosophy. In progressivism, the teachers valued interaction and participation as most important $(\overline{\mathrm{x}}=4.72$, and $\sigma=0.738)$, which is, of course, the highest-rated element in the various educational philosophies. In reconstructionism, the focus on creating responsible citizens rated highest $(\overline{\mathrm{x}}=4.53$, and $\sigma=0.775$ ). Similarly, in constructivism, the focus on developing students' own understanding reported the highest score $(\overline{\mathrm{x}}=4.51$, and $\sigma=0.714)$. In humanism, the focus on accountability in learning scored the highest $(\bar{x}=4.47$, and $\sigma=0.709)$. In positivism, the focus on the multicultural background of learners scored the highest $(\bar{x}=4.36$, and $\sigma=0.779)$. The interesting element here is the scores of factors in teacher-centered teaching and learning philosophy. In behaviorism, the focus of teaching as the role model scored the highest $(\bar{x}=4.57$, and $\sigma=0.697)$. It shows that though the teachers are focusing on student-centered teaching and learning philosophy, few of the elements of teachers centered teaching and learning philosophy are still considered important in maintaining 
effective teacher-student engagement in classrooms. This is evident in the higher scores of a few elements from the teacher-centered teaching and learning philosophies. It also calls upon the fact that the effective education philosophy in classrooms should be one which is formed by mixing the positive aspects of each philosophy. Similarly, in the essentialism principle, the focus on intellectual discipline in classrooms scored the highest $(\overline{\mathrm{x}}$ $=4.45$, and $\sigma=0.794)$. In perennialism, the focus on understanding the concepts in totality scored the highest $(\overline{\mathrm{x}}=4.45$, and $\sigma=0.794)$.

The mean and standard deviation ( $\overline{\mathrm{x}}$ and $\sigma$ ) of different elements in each educational philosophy are summarized in the following table.

Table 4. Dominant Education Philosophy

\begin{tabular}{|c|c|c|c|}
\hline \# & Focus & Mean & SD \\
\hline 1 & Focus on interaction \& participation & 4.7200 & 0.73778 \\
\hline 2 & Focus on customizing learning & 4.5400 & 0.76900 \\
\hline 3 & Focus on the needs of a dynamic environment & 4.5000 & 0.70176 \\
\hline 4 & Learning by pursuing own interest & 4.1550 & 0.98275 \\
\hline \multirow[t]{2}{*}{5} & Focus on practical and problem solving & 4.1150 & 0.83382 \\
\hline & Progressivism & 4.4060 & 0.63875 \\
\hline 6 & Focus on creating responsible citizens & 4.5300 & 0.77596 \\
\hline 7 & Focus on realism (address real problems in society) & 4.5550 & 0.65507 \\
\hline 8 & Focus on futuristic learning & 4.5500 & 0.73498 \\
\hline 9 & Focus on free expressions & 4.5300 & 0.74961 \\
\hline 10 & Focus on liberalism in discussion & 3.7100 & 1.12795 \\
\hline \multirow[t]{2}{*}{11} & Focus on creating constructive reforms & 4.1800 & 0.81912 \\
\hline & Reconstructionism & 4.3427 & 0.62485 \\
\hline 12 & Focus on developing own understanding & 4.5400 & 0.71481 \\
\hline 13 & Focus on recollection and relating knowledge & 4.4250 & 0.77289 \\
\hline 14 & Focus on experiential learning & 4.2950 & 0.78168 \\
\hline 15 & Focus on application-based learning & 4.1859 & 0.84124 \\
\hline 16 & Focus on freedom in learning & 4.0603 & 0.91364 \\
\hline 17 & Focus on interactive learning & 4.1809 & 0.83933 \\
\hline \multirow[t]{2}{*}{18} & Focus on relating learning to real life & 4.4000 & 0.74348 \\
\hline & Constructivism & 4.2991 & 0.62960 \\
\hline 19 & Focus on accountability in learning & 4.4724 & 0.70924 \\
\hline 20 & Focus on creative thinking & 4.4550 & 0.74211 \\
\hline 21 & Focus on enhancing curiosity to learn & 4.4300 & 0.74692 \\
\hline 22 & Focus on learning without stress & 4.0404 & 0.99153 \\
\hline 23 & Focus on compassionate learning & 4.0808 & 0.87465 \\
\hline 24 & Focus on self-evaluation and consented benchmarking & 3.8744 & 0.96363 \\
\hline 25 & Focus on motivation to learn & 4.4343 & 0.75618 \\
\hline \multirow[t]{2}{*}{26} & Focus on maintaining human dignity & 4.2060 & 0.85444 \\
\hline & Humanism & 4.2516 & 0.65849 \\
\hline 27 & Focus on multi-cultural background of learners & 4.3636 & 0.77988 \\
\hline 28 & Focus on exploring truth through experience \& knowledge & 4.3384 & 0.76844 \\
\hline \multirow[t]{2}{*}{29} & Focus on experiments and statistics in learning & 3.9849 & 0.90720 \\
\hline & Positivism & 4.226 & 0.68501 \\
\hline 30 & Teacher as a role model & 4.5750 & 0.69772 \\
\hline 31 & Focus on maintaining discipline and order & 3.8939 & 0.96847 \\
\hline 32 & Focus on time management & 4.4697 & 0.71715 \\
\hline
\end{tabular}


Table 4 Continued

\begin{tabular}{|l|c|l|l|}
\hline 33 & Monitoring students in and outside the class & 3.4850 & 1.11174 \\
\hline 34 & Focus on authoritative learning & 3.9850 & 0.92142 \\
\hline 35 & Focus on feedback in learning & 4.2714 & 0.77638 \\
\hline & Behaviorism & $\mathbf{4 . 1 1 2 9}$ & $\mathbf{0 . 6 2 0 4 6}$ \\
\hline 36 & Focus on intellectual discipline in classrooms & 4.2261 & 0.78117 \\
\hline 37 & Focus on interpreting the essentials of the subject & 4.3200 & 0.76847 \\
\hline 38 & Focus on memorization & 3.2663 & 1.28881 \\
\hline 39 & Focus on learning core concepts & 4.0402 & 0.94729 \\
\hline & Essentialism & $\mathbf{3 . 9 6 3 8}$ & $\mathbf{0 . 7 0 8 6 1}$ \\
\hline 40 & Focus on understanding concepts in totality & 4.4550 & 0.79444 \\
\hline 41 & Focus on concepts in learning & 4.1650 & 1.01138 \\
\hline 42 & Focus on fundamentals in learning & 4.4264 & 0.87535 \\
\hline 43 & Focus on the capability to learn & 3.3100 & 1.36867 \\
\hline 44 & Focus on exploring and self-discovery & 4.0950 & 0.80574 \\
\hline 45 & Lecturers' knowledge is unquestionable. & 2.9899 & 1.39982 \\
\hline 46 & Focus on the lecturer's knowledge in student learning. & 3.7538 & 1.13024 \\
\hline & Perennialism & $\mathbf{3 . 8 8 4 6}$ & $\mathbf{0 . 7 3 6 9 4}$ \\
\hline
\end{tabular}

Table 5. One Way ANOVA

\begin{tabular}{|c|c|c|c|c|c|c|c|c|c|c|}
\hline \multirow{2}{*}{} & \multicolumn{2}{|c|}{$\begin{array}{c}\text { Place of Work - } \\
\text { Name of HEI }\end{array}$} & \multicolumn{2}{|c|}{ Gender } & \multicolumn{2}{c|}{ Specialization } & \multicolumn{2}{c|}{$\begin{array}{c}\text { Years of } \\
\text { experience }\end{array}$} & \multicolumn{2}{c|}{ Nationality } \\
\cline { 2 - 13 } & $\mathrm{F}$ & Sig. & $\mathrm{F}$ & Sig. & $\mathrm{F}$ & Sig. & $\mathrm{F}$ & Sig. & F & Sig. \\
\hline Behaviorism & 3.247 & 0.005 & 2.216 & 0.138 & 0.560 & 0.761 & 2.045 & 0.069 & 0.721 & 0.397 \\
\hline Constructivism & 2.355 & 0.032 & 6.497 & 0.012 & 0.310 & 0.930 & 1.840 & 0.141 & 0.047 & 0.829 \\
\hline Essentialism & 1.226 & 0.295 & 0.746 & 0.389 & 0.751 & 0.609 & 1.285 & 0.281 & 0.066 & 0.797 \\
\hline Humanism & 2.517 & 0.023 & 5.078 & 0.025 & 0.891 & 0.501 & 2.320 & 0.077 & 0.049 & 0.826 \\
\hline Perennialism & 1.839 & 0.094 & 2.872 & 0.092 & 0.947 & 0.482 & 3.210 & 0.240 & 2.718 & 0.101 \\
\hline Positivism & 2.974 & 0.008 & 1.838 & 0.177 & 0.766 & 0.597 & 2.960 & 0.033 & 1.198 & 0.275 \\
\hline Progressivism & 2.181 & 0.046 & 3.542 & 0.061 & 0.700 & 0.650 & 1.500 & 0.216 & 0.001 & 0.977 \\
\hline Reconstructivism & 2.163 & 0.048 & 7.975 & 0.005 & 0.889 & 0.504 & 3.597 & 0.213 & 2.073 & 0.152 \\
\hline
\end{tabular}

An important observation evident from the one-way ANOVA is the influence of the place of work on the educational philosophy of staff. Table 1 summarizes the results of one-way ANOVA based on gender, specialization, place of work, years of experience, and nationality. As explained, recruitments in the seven CoTs are centrally managed. The analysis revealed the importance of the place of work, which is causing the difference in teacher's preference for educational philosophies. This result further reiterates that the teacher's educational philosophy is often influenced by his/her place of work.

The analysis also revealed that except the place of work, other factors such as the age of staff, their specialization, years of experience, and nationality are not significant factors that influence teaching philosophy selection. In other words, there exists no significant difference in the educational philosophy of teachers when classified based on their specialization, years of experience and nationality. There exists a difference in the perception of humanism and reconstructivism when the participants are classified based on their age. Humanism addresses students' overall development by considering their feelings and actions, and knowledge, which is more personalized in nature. On the other hand, a classroom that is centered on reconstructivism involves students in the discussion of moral dilemmas to understand own action.

To summarize, the analysis provided useful insights on how the underlying educational philosaphy shapes teaching practices. The use of good practices from various educational philosophies is evident in the analysis and statistical difference in preference of educational philosophies. It was evident only when the teachers were classified based on their place of work. 


\section{Discussion of the Findings}

An education philosophy provides a foundation for understanding and guiding decisions about curriculum, teacher-learner relationships, and professional practice. When we view a teachers' educational philosophy in this context, it is meaningful to conclude it as influenced by HEI strategic priorities. The vision and mission statements explain the preferred educational philosophy. For instance, in Colleges of Technology, the mission statement explains its core philosaphy as 'high-quality student-centered education that produces competitive graduates'. Strategic and operational plans provide details of implementation steps and key performance indicators to achieve the strategic priorities. Besides, CoT also specifies the core graduate attributes, which outline the specific skills and competencies a student will achieve by completing the study program. The achievement of strategic priorities is examined using both primary and secondary data. A set of survey instruments is available, for instance, student evaluation on teaching, student evaluation on programs, alumni feedback on programs, graduate feedback on programs and employers' feedback on programs. Thus, the approach is clearly articulated and moved to deployment using core teaching and learning activities. To align the teaching and learning activities to HEI vision and mission, the teachers must follow an educational philosophy that aligns with HEI priorities and philosophies. The present study attempted scrutiny of the alignment of HEI philosophy with the teachers' educational philosophy.

The logic of this research is deductive. We developed a hypothesis that the educational philosophies of teachers are often aligned with HEI educational philosophy. The analysis confirms a significant and positive correlation between the HEI philosophy and the teacher's dominant educational philosophy. Thus the research reiterates the statement that the teacher's role in the learning process is often defined by the education philosophy [51]. When the dominant philosophy among teachers is analyzed, progressivism, reconstructivism, constructivism, and humanism reflect CoT's teaching and learning practices. The basic notion behind such a teaching pedagogy is learners' acceptance as intellectually generative individuals capable of solving problems and constructing theories [44]. Thus, the research findings support earlier research findings highlighting the importance of progressivism, reconstructivism, constructivism, and humanism in teaching and learning. These philosophies are student-centered; hence, the results support the observation that teachers' educational philosophy is aligned to the HEI's educational philosophy. A clearly articulated educational philosophy's role is to provide prescriptive propositions offering normative advice to teachers on 'what to do', 'how to do', and 'why'. In this perspective, the teachers' philosophies are influenced by the underlying principles shared by the HEI. In the case of CoTs, a clearly defined mission statement "to provide high-quality student-centered education" answers the basic questions; 'What to do?', How to do?, and 'Why?'.

However, the notion that teachers select a particular educational philosophy as the most influential philosophy is not valid. This research highlighted that teachers blend various educational philosophies' positive aspects to deliver an effective classroom teaching methodology. Each educational philosophy has its own advantages and disadvantages. The relevance of graduate attributes and employability skills paved the way for active teaching and learning strategy, though the fundamental concepts are still imparted in a traditional classroom model. This further poses a question regarding the use of traditional teaching methodology. It is evident from the analysis that teachers also use a few elements of a teacher-centered philosophy, such as focusing on discipline in classrooms, focusing on attendance, focusing on fundamentals, and focusing on concepts. This also reflects a difference in what teachers perceive and what they implement in classrooms. In this context, the outcome of this research supports empirical research findings on the lack of alignment on how student-centered learning could and should be practiced considering the contextual factors [52]. Previous research studies also highlighted a positive and significant relationship between the adopted educational philosophy and the teaching style [49]. However, these findings differ from empirical findings that highlight the importance of teachers' philosophy in shaping their classroom behavior, course design, and the selection of pedagogical framework [50].

This research establishes the fact that HEI educational philosophy influences the teacher's educational philosophy. Though it is adhered by the teachers as observed in their preferred educational philosophy, a close examination of the philosophies with the graduate attributes reveals few interesting insights. For instance, to achieve the graduate attribute statement 1 , which is well disciplined and committed to hard work and a high standard of productivity, teachers mainly followed a blend of teacher-centered and student-centered teaching and learning philosophy such as (a) focus on accountability in learning $(\overline{\mathrm{x}}=4.47$, and $\sigma=0.709)$, (b) focus on maintaining discipline and order $(\overline{\mathrm{x}}=3.89$, and $\sigma=0.96)$, (c) focus on intellectual discipline in classrooms $(\overline{\mathrm{x}}=4.22$, and $\sigma=0.781$ ), and (d) focus on developing own understanding $(\overline{\mathrm{x}}=4.54$, and $\sigma=0.71)$. As observed, it blends major teaching philosophies that are adhered to achieve the graduate attributes. Further, it includes both students-centered and teacher-centered teaching and learning philosophies.

Finally, what influences the educational philosophy of teachers? Based on the analysis, we found that educational philosophy is influenced mainly by the HEI's underlying philosophy. This is evident from the ANOVA. Though the 
CoTs are centrally governed, teachers in every CoT is found to differ significantly in their views regarding preferred educational philosophy. It also poses a significant question. Whether teachers in all CoTs adhere to the articulated HEI's educational philosophy. Though a summative form confirms the adherence, the extent to which it has adhered differs among the various CoTs. This requires further examination and is considered as a scope of future studies. Besides, the underlying educational philosophy of other HEIs and the teachers preferred educational philosophy can be examined to gain more insights on the topic. The scale used in this research may also be examined for its consistency in a different academic context.

\section{Conclusions}

HEIs desperately need to align their educational philosophy with that of its faculty members. Often, the conflict arises between what an HEI intends its faculty to follow and what the faculty do in the classrooms. Basically, a faculty can follow student-centered or teacher-centered teaching and learning philosophies while teaching. Both approaches have positive and negative aspects. HEIs often articulate their teaching philosophies in the vision and mission statement, Graduate attributes provide useful insight on what an HEI wants its student to become, and it also provides an insight on how to teach and assess the students.

To create effective educational practices, HEI's educational philosophy should align with the individual educational philosophy of the educators. This is often a daunting task as educators vary in terms of their underlying educational beliefs. This study examined the dominant educational philosophy in Colleges of Technology, the second largest educational institution in the Sultanate of Oman. The study found that student-centered teaching and learning practices are dominant among educators, though the positive aspects of teacher-centered philosophy are also embedded in classrooms.

There is no right educational philosophy. Therefore, the effectiveness of teaching pedagogies depends on how well the HEI and the educators use each educational philosophy's positives to create a blended and more effective educational philosophy.

\section{Acknowledgments}

We are grateful to The Research Council (TRC) for providing support in conducting this research. The HoD's and academic staff members of Colleges of Technology support and cooperate to complete the study.

\section{REFERENCES}

[1] Andrews Acquah, Augustine Adjei, Jonathan Kwame Mensah, "School of thoughts of the essentialist philosophers on the aims of education, the role of education, and the focus of education: Implications for curriculum development and practice in Ghana," Journal of Philosophy, Culture, and Religion, Vol. 32, pp. 1-7, 2017. DOI: 10.7176/JPCR.

[2] Mgr. Adéla Antlová, Mgr. Štefan Chudý, Tereza Buchtová, Lucie Kučerová, "The Importance of Values in the Constructivist Theory of Knowledge," EPC-TKS, 2015, pp. 1-7, URL: https://www.journals.elsevier.com/procedia-soci al-and-behavioral-sciences.

[3] Richard, I, Arends, Nancy E. Winitzky, Margaret D Tannenbaum, "Exploring teaching: An introduction to education," New York: McGraw Hill, 2001

[4] Mohammed Arif, "Baldrige theory into practice: a generic model." International Journal of Education Management, Vol. 21, No. 2, pp. 114-125, 2007. DOI: $10.1108 / 09513540710729917$.

[5] Ghokan Bas, "Correlation between teachers' philosophy of education beliefs and their teaching-learning conception," Education and Science, Vol. 40, No. 182, pp. 111-126, 2016. DOI: 10.15390/EB. 2015.4811

[6] Gert Biesta, "What is education for? On good education, teacher judgment, and educational professionalism," European Journal of Education, Vol. 50, No. 1, pp. 75-87. 2015. DOI: 10.1111/EJED.12109.

[7] Diane Billings, Judith Halstead, "Teaching in Nursing, a guide for faculty," $6^{\text {th }}$ Ed, St. Louis, MO: Saunders Elsevier, 2009., pp.1-608.

[8] Sergey Borisov, "Ideas of constructivism in the philosophy of education: from ontology to phenomenology," Life Science Journal, Vol. 11, No. 11, pp. 399-402, 2014.

[9] Theodore Brameld, "Reconstructionism as Radical Philosophy of Education: A Reappraisal," The Educational Forum, Vol. 42, No. 1, pp. 67-76, 1977.

[10] Mustafa Cakir, "Constructivist Approaches to Learning in Science and Their Implications for Science Pedagogy: A Literature Review," International Journal of Environmental \& Science Education, Vol. 3, No. 4, pp. 193-206, 2007.

[11] Omay Cokluk, Murat Kayri, "The effects of methods of imputation for missing values on the validity and reliability of scales," Educational Sciences: Theory and Practice, Vol. 11, No. 1, pp. 303-309, 2011.

[12] Jose M Cortina, "What is coefficient alpha? An examination of theory and applications," Journal of Applied Psychology, Vol. 78, No. 1, pp. 98-104, 1993. DOI: 10.1.1.527.7772.

[13] Lisa Dieker, Craig Berg, Bobby Jeanpierre, "Directions for change in blending science instruction and special education," in Personnel Preparation Advances in Learning and Behavioral Disabilities, Bingley: Emerald Publishing House, Vol. 21, 2008, pp. 253-275.

[14] Fausan Akmal Firdaus, Akrim Mariyat, "Humanistic approach in education: According to Paulo Freire," At Ta' dib, Vo. 12, No. 2, pp. 25-48. 2017. DOI: 10.21111/at-tadib.v12i2.1264. 
[15] Melehat Gezer, "An analysis of correlations between prospective teachers' philosophy of education and their attitudes towards multicultural education," Cogent Education, Vol. 5, No. 1, pp. 1-22, 2018. DOI: 10.1080/2331186X.2018.1475094.

[16] George Graham, "Behaviorism," Stanford Encyclopedia of Philosophy: https://plato.stanford.edu/entries/behaviorism/ (accessed September 1, 2020)

[17] Graham D Hendry, Miriam Frommer, Richard A Walker, "Constructivism and Problem based Learning," Journal of Further and Higher Education, Vol. 23, No. 3, pp. 359-371, 1999. DOI: $10.1080 / 0309877990230306$

[18] William H Howick, "Philosophies of Education," $1^{\text {st }}$ Ed, Danville: Interstate Printers and Publishers Inc. 1971.

[19] Qiong Jia, “A Brief Study on the Implication of Constructivism Teaching Theory on Classroom Teaching Reform in Basic Education," International Educational Studies, Vol.3, No. 2, pp. 197-199, 2010. DOI: /EJ1066095.

[20] Kimberly J. Karhof "Analysis of Four Current Educational Philosophies and Their Impact on Science Education: Towards a Reformed Christian Philosophy of Science Education" Master of Education Program Thesis, Dordt College. 2003. https://digitalcollections.dordt.edu/cgi/viewc ontent.cgi? article $=1077 \&$ context $=$ med theses .

[21] Khatib Mohammad, Saeid Sarem, Hadi Hamidi, "Humanistic Education: Concerns, Implications and Applications," Journal of Language Teaching and Research, Vol. 4, No. 1, pp. 45-51, 2013. DOI: 10.4304/jltr.4.1.45-51.

[22] Canan Kocak, F Merve Ulusoy, Aysem Seda Onen, "Investigation of teacher candidates' identity functions and educational beliefs," in The X. National science and mathematics education congress. Nigde University. 2012. https://www.pegem.net/Akademi/kongrebildiri_detay.aspx? id=135942 (accessed September 1, 2020)

[23] Chokri Kooli, Chiraz Zidi, Ahmad Jamrah, "The Philosophy of Education in the Sultanate of Oman: Between Perennialism and Progressivism," Amercian Journal of Education and Learning, Vol. 4, No. 1, pp. 36-49. 2019. DOI: 10.20448/804.4.1.36.49.

[24] Ian PM Lambert, "Educational philosophy: what is it all about?," The Scots College, https://www.tsc.nsw.edu.au/tsc news/educational-philosophy-what-is-it-all-about (accessed September 1, 2020)

[25] Qin Lei, "EFL teachers' factors and students" affect," US-China Education Review, Vol. 4, No. 3, pp. 60-67, 2007.

[26] Jyri Linden, Johana Annala, Kelly Coate, "The Role of Curriculum Theory in Contemporary Higher Education Research and Practice," in Theory and Method in Higher Education Research,. Emerald, Vol 3, pp. 137-154 2017. DOI: $10.1108 / \mathrm{S} 2056-375220170000003008$

[27] Jim Mackenzie, "Positivism and Constructivism, Truth and 'Truth'," Education Philosophy and Theory, Vol. 43, pp. 534-546, 2010. DOI: 10.1111/j.1469-5812.2010.00676.

[28] Michael R. Matthews, "Reappraising Positivism and Education: The Arguments of Philipp Frank and Herbert Feigl," Science and Education, Vol. 13, pp. 7-39. 2004. DOI: 10.1023/B:SCED.0000018544.34295.8b

[29] Mark R McCoy, "Teaching style and the application of adult learning principles by police instructors. Policing," An International Journal, Vol. 29, No. 1, pp. 77-91, 2006. DOI: $10.1108 / 13639510610648494$

[30] Peter Mclaren, Raman Farahmandpur, "Teaching against global capitalism and the new imperialism - A Critical Pedagogy New," $1^{\text {st }}$ Ed, Rowan and Littlefield Publishers Inc. 2005. Pp. 1-320.

[31] Jim Minstrell, Pamela A Kraus, "The teaching and learning of physics," in Subject-specific instructional methods and activities - Advances in Research on Teaching, Bingley: Emerald Group Publishing Limited Vol. 8, pp. 215-238, 2001. DOI: 10.1016/S1479-3687(01)80028-6.

[32] Ken Plummer, "Critical humanism in a post-modern world," in Studies in Symbolic Interaction (Studies in Symbolic Interaction, Bingley: Emerald Group Publishing Limited, Vol. 25, pp. 293-303, 2002. DOI: 10.1016/S0163-2396(02) 80053-9.

[33] David Scott Poracro, "Applying constructivism in instructivist learning cultures," Multicultural Education \& Technology Journal, Vol. 5, No. 1, pp. 39-54, 2011. DOI: $10.1108 / 17504971111121919$

[34] Mark Priestley, "What happened to curriculum theory? Critical theory and curriculum change. Pedagogy," Culture and Society, Vol. 19, No. 2, pp. 221-237, 2011. DOI: $10.1080 / 14681366.2011 .582258$.

[35] Mohammad Rob, Farhana Rob, "Dilemma between constructivism and constructionism: Leading to the development of a teaching-learning framework for student engagement and learning," Journal of International Education in Business, Vol. 11, No. 2, pp. 273-290, 2018. DOI: 10.1108/JIEB-01-2018-0002.

[36] Anastasia P Samaras, Anne R Freese, "Self Study of Teaching Practices," $1{ }^{\text {st }}$ Ed, Peter Lang Publishing Inc, 2006, pp. 1-175.

[37] Abbas Abdoli Sejzi, Baharuddin bin Aris, "Constructivist Approach in Virtual Universities," International Conference on Teaching and Learning in Higher Education, Johor, Malaysia: Elsevier Publishing, 2012, pp. 426-431.

[38] Harvey Siegel, D C Philips, Eamonn Callan, "Philosophy of Education," Stanford Encyclopedia of Philosophy, : https://plato.stanford.edu/entries/education-philosophy/ (accessed September 1, 2020)

[39] Sonmez, "Educational Philosophy," $1^{\text {st }}$ Ed, Ankara: Ani Publishing. 2002

[40] Keith S Taber, "The Use of Cronbach's Alpha When Developing and Reporting Research Instruments in Science Education," Research in Science Education Vol. 48, pp. 1273-1295. 2018. DOI: 10.1007/s11165-016-9602-2

[41] Keith Thompson, "The philosophy of education," Education + Training, Vol. 16, No. 2/3, pp. 56-58, 1970. DOI: 10.1111/j.1467-9752.1970.tb00426.x.

[42] Duygu Turker, Senem Sonmaz Selcuk, "Which factors affect the entrepreneurial intention of university students?," Journal of European Industrial Training, Vol. 33, No. 2, pp. 142-159, 2009. DOI: 10.1108/03090590910939049.

[43] Emel Ultanir, “An epistemological glance at the constructivist approach: constructivist learning in Dewey, 
Piaget and Montessori," International Journal of Instruction, Vol. 5, No. 2, pp. 195-212, 2012.

[44] Kaya Yilmaz, “Constructivism: Its Theoretical Underpinnings, Variations, and Implications for Classroom Instruction," Educational Horizons, Vol/ 86, pp. 161-172, 2008.

[45] Kursad Yilmaz, Yahya Altinkurt, Omay Cokluk, "Developing the Educational Belief Scale: The Validity and Reliability Study," Educational Sciences: Theory \& Practice, Vol. 11, No. 1, pp. 343-350, 2011.

[46] Tiffany Young, "A Qualitative Self-Study of Educational Philosophy Within the Context of a Structured Educational Framework," Ann Arbor: Lindenwood University - Ph.D. Dissertation, 2019

[47] Gurol Zirhlioğlu, Ahmet Yayla, "The Investigation of the Education Philosophy of the Education Faculty Students of Yuzuncu Yil University with the Q Method," Universal Journal of Educational Research, Vol. 4, No. 9, pp. 2110-2118. DOI: 10.13189/ujer.2016.040923

[48] Lisa Janicke Hinchliffe, Bath S Woodard, "The teaching philosaphy framework: Learning, leading and growing," Loex, pp.213-221. 2011.

[49] Emel Saritas, "Relationship between philosophical preferences of classroom teachers and their teaching styles," Educational Research and Reviews, Vol.11, No. 16. 2016. DOI: 10.5897/ERR2016.2787

[50] Joy E Beatty, Jennifer S A Leigh, Kathy Lund Dean, "Philosaphy Rediscovered - Exploring the connections between teaching philosophies, educational philosaphy, and philosaphy," Journal of Management Education, Vol. 33, No. 1, pp. 99-114. 2009. DOI: 10.1177/1052562907310557

[51] Cindi H Fries, "Teaching style preferences and educational philosaphy of teacher education faculty at a state university," Dissertation submitted to North Eastern State University, 1982. URL: https://shareok.org/bitstream/handle/11244/721 6/Fries_okstate_0664D_12226.pdf?sequence $=9$

[52] Saed Sabah, Xiangyun Du, “University faculty's perceptions and practices of student centered learning in Qatar: Alignment or gap?", Journal of Applied Research in Higher Education, Vol.10, No. 4m pp.514-533, 2018. 